\title{
UNESCO: SOME COMMENTS ON PURPOSE, PROGRAM AND ADMINISTRATION
}

\author{
LUKE T. LEE*
}

TYPICAL OF recent requests and expectations for UNESCO's services was the following resolution sponsored by Iran and adopted without dissent by the 1964 United Nations Conference on Trade and Development in Geneva:

Development needs of education and science

The Conference

Recommends that the participating Governments should give due consideration, in the context of their trade and assistance policies, to the development needs of education and science;

Recommends that the United Nations Educational, Scientific and Cultural Organization (UNESCO) should continue, in collaboration with the international agencies concerned, its programme to promote the international circulation of educational, scientific and cultural material;

Invites UNESCO to continue, in consultation with the other international agencies concerned, its studies of the international trade in educational and scientific material as a factor in accelerating the development of the developing countries;

Invites UNESCO to continue to keep the United Nations informed concerning the above mentioned studies and submit recommendations to the Economic and Social Council and whatever other organ of the United Nations system seems appropriate in the light of the recommendations of the United Nations Conference on Trade and Development. ${ }^{1}$

UNESCO has indeed responded generously to these new callings from the developing nations, based on the conceptual idea that education is a prime constituent for economic development. ${ }^{2}$ In

- B.A. 1944, St. John's University (Shanghai); M.A. 1947, Columbia University; Ph.D. 1954, Fletcher School of Law \& Diplomacy; LL.B. 1963, University of Michigan. Director of New York Office, Rule of Law Research Center, and Lecturer in Law, Duke University.

1 United Nations Conference on Trade and Development, Annex A.VI.9, U.N. Doc. No. E/CONF. 46/L.28 (1964); see U.N. Doc. No. E/CONF. 46/SR.35, at 47 (1964).

'See UNESCO Director-General, International Trade in Educational and Scientific Materials, U.N. Doc. No. E/CONF. 46/53, at 4 (1964).

Plans have been drawn up at conferences convened by UNESCO for the develop- 
the words of the Secretary-General of the United Nations Conference on the Application of Science and Technology for the Benefit of the Less Developed Areas, held in Geneva in February, 1963:

The core of human resource development is the planning and execution of a policy of education and training-two aspects of the same co-ordinated process designed to provide the trained manpower at all levels of skill required to achieve the objectives of the economic development plan. ${ }^{3}$

That the underdeveloped countries consider illiteracy a top priority in their plans for development was underscored by Mr. René Maheu, Director-General of UNESCO, at the 1964 summer session of the United Nations Economic and Social Council. ${ }^{4}$ Stressing that the map of the world's illiteracy is practically identical with that of underdevelopment, Mr. Maheu submitted a report in October 1963 to the General Assembly on the eradication of illiteracy from the world. 5 The Assembly adopted unanimously a resolution calling for a world campaign for universal literacy. ${ }^{\circledR}$ It invites

ment of education in Africa, Asia and Latin America. See Reports of the Regional Meeting of Representatives of Asian Member States on Primary and Compulsory Education (Karachi, 1960); Report of the Meeting of Ministers of Education of Asian Member States (Tokyo, 1962); Reports of the Conference of African States on the Development of Education in Africa (Addis Ababa, 1961); and Report of the Regional Conference on Free and Compulsory Education in Latin America (Lima, 1956).

In order to meet the growing demand for educational planning, the International Institute for Educational Planning was established in Paris two years ago as a part of UNESCO. At this writing, it is still in its embryonic stage, with a staff of only four or five. Its main activities include planning of school curricula and administration, giving advice thereon, and holding seminars to exchange views and experiences on educational planning between different geographical regions. Participants of the seminars are drawn from government officials, economists, and school teachers and administrators. Reports on the seminars' work will be published for the benefit of the general public. A twenty-five man, five-week seminar on Latin American planning has already been held, and an African seminar was to be held in 1965. Interview with Jose Correa of the Institute in Paris, Aug. 19, 1964.

Dr. A. Lewis, economist and former Deputy Director of the United Nations Special Fund, emphasizes the importance of producing large numbers of secondary school graduates in developing economies. This "middle group" would provide the indispensible human resource base for development. Ellis, Secondary Education and the Developing Countries (unpublished article).

3 Conference Secretary-General, Report, United Nations Conference on tiie APPlication OF Science and Technology for the Benefit of the LeSS Developed AREAS: HuMAN RESOURCES \ 24.

'See U.N. Doc. No. A/C.2/L.731 (1963); Maheu, The Struggle Against Illiteracy, UNESCO Courier, Oct. 1964, p. 6.

${ }^{5}$ U.N. Doc. No. E/3771 and Corr. 1 \& 2 (1968). The report was requested by the General Assembly and approved by the General Conference of UNESCO at its 12th session. It was transmitted through the Economic and Social Council.

'Res. No. 1937 (XVIII), U.N. GEN. Ass. OFF. Rec. 18th Sess., Plenary 1276 (A/5653) (1963). 
member states with a high porportion of illiteracy to intensify their efforts to reduce illiteracy within their over-all development plans, and requests those with a high literacy rate to render all necessary assistance, whether technical or financial. UNESCO, along with the United Nations Technical Assistance and Special Fund, the International Bank for Reconstruction and Development, and the United Nations itself, was urged "to explore ways and means of supporting national efforts for the eradication of illiteracy through a world campaign and any other measures, if appropriate, of international co-operation and assistance, both non-financial and financial, and to submit a report thereon, together with appropriate proposals, to the General Assembly at its nineteenth session."

These new emphases on UNESCO's educational role in the development of the newly emergent nations are perhaps brought out nowhere more vividly than in the following statistics: Almost one-half of UNESCO's total budget for 1965-1966 would come from the United Nations Technical Assistance and Special Funds; ${ }^{8}$ approximately two-thirds of its regular budget (excluding the extrabudgetary resources from the United Nations Technical Assistance and Special Funds) for 1963-1964 was used to assist the newly developing countries; ${ }^{9}$ and, in the mushrooming of UNESCO's activities throughout the world-a total of 1,158 field posts already filled or soon to be filled ${ }^{10}$-the dominant theme is the educational development of the newly emergent nations. In sum, this "NorthSouth Major Project" has indubitably come to overshadow the "East-West Major Project," due to terminate in 1966.11

But in the flurry of these activities, there is the grave danger that the original purpose of UNESCO might be forgotten. While continual innovations of a society or organization must be encour-

7 Ibid.

${ }^{8}$ See UNESCO, Introduction, Draft Programme and Budget for 1965-1966, I 24 (1964). The regular budgetary resources proposed for the period in question would be $\$ 46,460,000$ or $50.1 \%$ of the total budget; whereas the extra-budgetary resources would be $\$ 46,190,000$ or $49.9 \%$, with Technical Assistance contributing $\$ 16,190,000$ or $17.5 \%$, and Special Fund contributing $\$ 40,000,000$ or $32.4 \%$.

- Benton, Progress Report on UNESCO, Saturday Review, March 7, 1964, p. 16, at 17.

${ }^{10}$ Figure compiled by William J. Ellis, Chief of the Reports Division, Bureau of Relations with Member States, UNESCO, Aug. 21, 1964.

${ }^{21}$ The "East-West Major Project" was created at the ninth session of the general conference to last ten years (1957-1966). Its complete title is the Mutual Project on Mutual Appreciation of Eastern and Western Cultural Values. See UNESCO, Draft Programme and Budget for 1965-1966, pt. II, ch. 3A, If 2 (1964). See also paragraph accompanying note 69 infra. 
aged to prevent it from falling into decay-what John W. Gardner, former president of the Carnegie Corporation and now Secretary of the Department of Health, Education and Welfare, called the need for "self renewal"12-the basic values or goals must nevertheless remain constant as a guide to all its programs. The latter must be tailored to suit the purpose, and not vice versa. Furthermore, it is also time to re-examine the organization, operation and personnel policy of UNESCO in the light of its nearly two decades of experience and experimentation and of the vastly increased membership and changing nature of its activities. The designation of 1965, the twentieth anniversary of the United Nations, as the International Co-operation Year ${ }^{13}$ atop that of the 1960's as the "United Nations Development Decade"14 has provided the ideal setting for a study of UNESCO.

\section{I}

\section{PuRPose of UNESCO}

Ever since its founding, UNESCO's precise purpose has been in debate. One school maintains that the strengthening of education, science, and culture will itself promote human welfare and thus lay the foundation for peace and security in the long run. It draws as its support the preamble of the constitution of UNESCO which defines its objectives in terms of "international peace and of the common welfare of mankind,"16 as well as section 2 (b) of article I of the constitution, which authorizes UNESCO, among other things, to "give fresh impulse to popular education and to the spread of culture; by collaborating with Members, at their request, in the development of educational activities." The second school argues that UNESCO's purpose is to contribute directly to peace

\footnotetext{
12 See generally GARDNER, SELF RENEWAL (1964).

${ }^{18}$ Res. No. 1844 (XVII), U.N. GeN. Ass. OfF. Rec. 17th Sess., Plenary 1198 (A/L.419 \& Add.1) (1962); see 1962 YEARBOOK OF UNITED NATIONS 55-57.

${ }^{24}$ At the suggestion of President Kennedy in a speech before the General Assembly on Sept. 25, 1961, the Assembly adopted unanimously a resolution designating the 1960 's as the "United Nations Development Decade." Res. No. 1710 (XV1), U.N. GEN. Ass. OFF. Rec. 16th Sess. (A/5056) (1961); see 1961 YeArBoor of UNITED NATIONS 228-32.

${ }^{15}$ Emphasis added. Although a preamble is generally regarded as having no operative force, the particular phrase "common welfare of mankind" has been cited many times by many delegates in General Conferences and by Julian Huxley, UNESCO's first Director-General, as one of UNESCO's major objectives. LAVEs \& THOMSON, UNESCO 32 (1957).
} 
and security, towards which goal UNESCO's activities must be oriented. ${ }^{16}$ It justifies its position on the war-torn background in which UNESCO was founded and, more specifically, on section 1 of article I of the constitution. ${ }^{17}$ Neither school, it must be noted, has ever completely dominated the policy-making process of UNESCO. ${ }^{18}$ In view of the recent shift of emphasis in UNESCO's activities, a re-examination of its original purpose is timely and justified.

The preamble to the constitution of UNESCO, adopting the words of Mr. Attlee, states that "since wars begin in the minds of men, it is in the minds of men that the defenses of peace must be constructed ...."19 It specifically warns against "a peace based exclusively upon the political and economic arrangements of governments," because such a peace could not "secure the unanimous, lasting and sincere support of the peoples of the world ..." Section 1 of article I then sets forth the purpose of UNESCO as contributing

to peace and security by promoting collaboration among the nations through education, science and culture in order to further universal respect for justice, for the rule of law and for the human rights and fundamental freedoms which are affirmed for the peoples of the world, without distinction of race, sex, language or religion, by the Charter of the United Nations. ${ }^{20}$

10 "But one cannot forget that the constitutive Act fixes also for UNESCO one other goal, more elevated still in the hierarchy of moral values, that of 'maintenance of peace and of security between nations.' To take the statutes of the Organization in their spirit and in their letter, everything that it accomplishes, in whatever technical domain of its competence, should not count for much if it cannot avail itself of contributing by its acts to the maintenance of peace in the world.... According to the perspective that the founders of UNESCO traced for it, the maintenance of peace must be considered by it as a superior duty to all the others and to which all the others are subordinated." THOMAs, U.N.E.S.C.O. 186-87 (1962) (translation).

"The key word... is the word 'through.' UNESCO would achieve its purpose through science, culture, education, the mass media and so on. In short, these were deliberately made a means to a practical goal, not ends in themselves. UNESCO was not designed to add to the sum of human knowledge. It was not a .classroom on a world scale. It was a medium through which culture and learning could be apphed to the practical problem of maintaining peace, and advancing the common welfare as represented by the United Nations." Dexter, Yardstick for UNESCO, 28 FOREIGN AfFairs 56, 59 (1949).

${ }^{17}$ See text accompanying note 20 infra.

${ }^{18}$ See LAVES \& THOMSON, UNESCO, 32-36 (1957).

${ }^{10}$ A wealth of literature exists on the "minds of men" theory. See, e.g., DuNN, WAR ANd the Minds of MEN (1950); HiLl, INTERnational Relations (1950); Whitton \& Larson, Propaganda (1964).

so Emphasis added. 
It may be seen that the purpose of UNESCO is not limited to peace and security-a common objective for the entire United Nations system as well as a relative concept dependent on the political, ideological, or military context in which it is used. More specifically, the purpose of UNESCO is to further justice, the rule of law, human rights, and fundamental freedoms-a legal concept, objectively definable. International collaboration in the fields of education, science and culture is but a means to an end. To replace the end by the means, as has been done in many of its recent acivities, would exceed the competence of UNESCO.

Not only is a reversal of the ends and means not authorized by the constitution of UNESCO, but its desirability is very much in question. The rationale for the current emphasis on education, science and culture as ends in themselves is that, by eliminating illiteracy, by building more schools, and by promoting international cultural and scientific exchanges, the necessary base for industrialization will have been built and peace preserved. But the linking of industrialization to peace is based on a shaky premise; forgotten is the recent history of mankind in which great and savage wars were fought not between illiterate, poverty-stricken peoples, but between nations of high literacy rate, cultural attainments, and scientific and industrial developments. ${ }^{21}$ Furthermore, industrial, agricultural and financial assistance lies more properly within the sphere of competence of organizations like the International Monetary Fund, the International Bank for Reconstruction and Development, the Food and Agricultural Organization, and the United Nations Technical Assistance and Special Funds. ${ }^{22}$ While UNESCO should lend its services to these organizations in relation to education, science and culture, it should not transform itself into a mere executing agent for them. ${ }^{23}$ Such services should at best be viewed as short-

${ }^{21}$ See Tripp, UNESCO in Perspective, 497 INT'L CoNc. 338, 340-41 (1954).

Professor Hans J. Morgenthau questions whether international understanding by itself could eliminate war, citing numerous examples of wars between countries which knew each other only too well. Morgenthau, Politics Among Nations 523.24 (3d ed. 1961). See Niebuhr, The Theory and Practice of UNESCO, 4 INT'L ORGAN. 3, 6 $(1950)$.

${ }_{22}$ The purposes and philosophical bases for functional agencies are succinctly stated in Mitrany, a Working Peace System (1946).

${ }^{23}$ The Director-General of UNESCO himself warns against this trend. Sec UNESCO, Introduction, Draft Programme and Budget for 1965-1966, I 30 (1964). 
term emergency measures, conditioned further upon a willingness for self-help by the recipient nations. It is no accident that section 2 (b) of article I of the constitution of UNESCO should use the word "collaborating," which denotes mutuality, instead of "assisting," which denotes unilateralism.

Although it is true that section 2 (b) of article I of UNESGO's constitution also authorizes UNESCO to "give fresh impulse to popular education and to the spread of culture," these and other activities are subject to the over-all limitation that they serve to realize the purpose enunciated in section 1 , as required by the introductory phrase of section 2. Thus, there is no doubt that if the type of educational activity requested by a member state is contrary to or does not serve the purpose of UNESCO, the latter is prohibited from rendering it.

In the light of the above discussion, a critical reappraisal of UNESCO's program and direction should be undertaken with a view to their realignment in conformity with the purpose of UNESCO-the furthering of universal respect for justice, the rule of law, human rights, and fundamental freedoms. Activities having no rational connection whatever with this purpose should be terminated at the earliest possible date. Where a connection is feasible but not yet established, appropriate actions should be taken toward its establishment. Where such a connection has already existed, consideration should still be given toward strengthening it. $^{24}$

But any attempt at such a reappraisal would immediately be confronted with the problem of time and space: It would fill volumes if all the significant projects undertaken by UNESCO were to be given a systematic re-evaluation. Furthermore, such a reevaluation would more properly and effectively be undertaken by the Secretariat of UNESCO, and in particular by the respective program departments. Instead, what follows are suggestions on certain phases of UNESCO's activities, selected for their importance, timeliness, and relationship to UNESCO's central purpose.

\footnotetext{
36 "[T] point is important that functional agencies are legitimate parts of the institutional structure of a world which desperately needs peace only if they maintain the steady pursuit of objectives reasonably related to the quest for peace. The resources of international organization in the mid-twentieth century are too limited to permit their being frittered away on trivialities." Claude, SwOrds into Plowshares 396 (2d ed. 1959).
} 


\section{II}

\section{PROGRAMS}

A. Teaching, Study, Dissemination and Wider Appreciation of International Law

It is probably true that the eradication of illiteracy as a major program of UNESCO is here to stay. This can be justified on the ground that the purpose of UNESCO-the universal furthering of respect for justice, the rule of law, human rights and fundamental freedoms-cannot be fulfilled without a literate citizenry, a goal which, incidentally, is equally indispensable to economic development. However, literacy is but a means to an end. Standing alone, it could be an effective and devastating tool for aggression, as the recent history of Germany and Japan has amply testified. A literacy campaign, therefore, must be paralleled by the adoption of appropriate contents for instruction, if it is to further the cause of international peace and security. While UNESCO has attained a measure of success in developing textbooks and disseminating information on many areas of natural and social sciences, it has been peculiarly remiss in one important area-international law.

It is not altogether fortuitous that the framers of the constitution of UNESCO should define its purpose in terms of justice and law. For war, or the resort to force in the settlement of international disputes, stems from the negation and violation of lawinternational law, which embodies such age-old rules as the respect for the sovereign equality of states and non-intervention in affairs within the domestic jurisdiction of other states. ${ }^{25}$ Even the charter

${ }^{25}$ The General Assembly created a Special Committee on Principles of International Law concerning Friendly Relations and Co-operation among States to study the following principles:

"(a) The principle that States shall refrain in their international relations from the threat or use of force against the territorial integrity or political independence of any State, or in any other manner inconsistent with the purposes of the United Nations;

"(b) The principle that States shall settle their international disputes by peaceful means in such a manner that international peace and security and justice are not endangered;

"(c) The duty not to intervene in matters within the domestic jurisdiction of any State, in accordance with the Charter;

"(d) The principle of sovereign equality of States . . ." Res. No. 1815 (XVII), U.N. GEN. Ass. OFF. Rec. 17th Sess., Supp. No. 15 (A/5356) (1962). See Res. No. 1966 (XVIII), U.N. GEN Ass. Off. Rec. 18th Sess., Supp. No. 15 (A/5515) (1963).

The Special Committee met in Mexico City from Aug. 27 to Oct. 2, I964, but 
of the United Nations is a part of international law, distinguished for its near universalism and overriding effects. Indeed, the United Nations itself operates within the framework of international law and seeks to strengthen it.

While the United Nations system includes a judicial organ in the International Court of Justice, the court, by its very nature, must operate in an isolated atmosphere, free from the influence and pressure of public opinions, if it is to preserve its integrity and impartiality. It is not within the court's function to propagate the knowledge of law, except indirectly through the decisions it makes and the resultant compliance therewith by states.

The same is true with the United Nations International Law Commission. Composed of twenty-five jurists representing the main legal systems of the world, the Commission is charged with the function of promoting the progressive development of international law and its codification. Its labor has born fruits in recent years through the conclusion of such multilateral treaties as the 1958 Geneva Conventions on the Law of the Seas, ${ }^{26}$ the 1961 Convention on Reduction of Statelessness, ${ }^{27}$ the 1961 Vienna Convention on Diplomatic Relations, ${ }^{28}$ and the 1963 Vienna Convention on Consular Relations ${ }^{29}$-all of which are based substantially on the drafts adopted by the Commission. More projects are now under way to codify such basic areas of international law as the laws of treaties ${ }^{30}$

succeeded in reaching consensus only on principle (d). A description and analysis of the major issues in the Mexico Gity conference are contained in Special Committee, Draft Report, U.N. Doc. No. A/AC/119/L.34 (1964), and in Lee, The Mexico City Conference of the United Nations Special Committee on Principles of International Law Concerning Friendly Relations and Co-operation Among States, 14 INT'L \& CoMP. L.Q. 1296 (1965).

28 Convention on the Territorial Sea and the Contiguous Zone, U.N. Doc. No. A/CONF. 13/L.52 (1958); Convention on the High Seas, U.N. Doc. No. A/CONF. 13/L.53 \& Corr.I (1958); Convention on Fishing and Conservation of the Living Resources of the High Seas, U.N. Doc. No. A/CONF. 13/L.54 \& Add.1 (1958); Convention on the Continental Shelf, U.N. Doc. No. A/CONF. 13/L.55 (1958).

${ }^{27}$ U.N. Doc. No. A/CONF. 9/15 (1961).

${ }^{28}$ U.N. Doc. No. A/CONF. 20/14/Add.1 (1961).

${ }^{\circ}$ U.N. Doc. No. A/CONF. 25/16/Add.1 (1963).

${ }^{30}$ For the evolution of successive drafts, see Brierly, Special Rapporteur, Reports, U.N. Doc. Nos. A/CN.4/23 (1950), A/CN.4/43 (1951), A/CN.4/54 (1952); Lauterpacht, Special Rapporteur, Reports, U.N. Doc. Nos. A/CN.4/63 (1953), A/CN.4/87 \& Corr.1 (1954); Fitzmaurice, Special Rapporteur, Reports, U.N. Doc. Nos. A/CN.4/101 (1956), A/CN.4/107 (1957), A/CN.4/115 \& Corr.1 (1958), A/CN.4/120 (1959), A/CN.4/130 (1960); Waldock, Special Rapporteur, Reports, U.N. Doc. Nos. A/CN.4/144 \& Add.1 (1962), A/CN.4/156 \& Adds.1-3 (1963), A/CN./167 \& Adds.1-3 (1964), A/CN.4/177 \& Add.1 (1965). 
and state responsibility. ${ }^{31}$ Their codifications would immeasurably promote the peaceful settlement of international disputes and the rule of law. But the International Law Commission, like the court, does not have as its specific duty the education of the common people toward respect for justice and the rule of law. Its publications are couched in technical, legal language understandable to lawyers but not laymen.

Yet the popularization of the elementary rules of international law among the peoples of all nations is essential if there is to be a "universal" respect for justice and the rule of law. The minds of all men-not just those of the politicians and lawyers-must therefore become depositories of knowledge concerning international law. Only in this way can a lasting peace be built. Indeed, the benefit will not end here, for the resultant enlightened citizenry can assert influence upon their governments not only toward observance of international law, but centripetally toward the fulfillment of the rule of law even within the domestic realm.

One may note with satisfaction that much has been and is being done by UNESCO in the area of human rights and fundamental freedoms through the implementation of the relevant provisions of the Universal Declaration of Human Rights of 1948. In the area of international law, however, nothing significant has been accomplished other than sponsoring a book, THE UNIVERSITY TEACHING OF Social Sciences: Law, by Charles Eisenmann in 1954, and a few multilateral treaties of a technical nature. ${ }^{32}$ This reluctance on the part of UNESCO to undertake systematically the dissemmation of legal knowledge in the way it has done with respect to human rights and racial equality may in part be attributable to an erroneous concept which, nevertheless, has gained currency in many parts of the world: that law is the business of lawyers. However, just as politics is no longer the monopoly of politicians, law, now

31 Mr. Robert Ago of Italy was appointed Special Rapporteur for the topic of state responsibility. International Law Comm'n, Report, U.N. GEN. Ass. OFF. REC. I8th Sess., Supp. No. 9, at 36 (A/5509) (1963).

32 E.g., Universal Copyright Convention, 1952; International Convention for the Protection of Performers, Producers of Phonograms and Broadcasting Organizations, 1961; Convention and Protocol for the Protection of Cultural Property in the event of Armed Conflict, 1962; Convention concerning the Exchange of Publications, 1958; Convention concerning the Exchange of Official Publications and Government Documents between States, 1958; proposed Convention against Discrimination in Education. 
re-affirmed by article I of UNESCO's constitution, should no longer be the exclusive concern of lawyers.

Realizing that once international law becomes more widely known and accepted, peace will be made more secure, ${ }^{33}$ the United Nations General Assembly on December 18, 1962, adopted Resolution 1816 (XVII), entitled "Technical assistance to promote the teaching, study, dissemination and wider appreciation of international law." Its operative part stated that the General Assembly:

1. Urges Member States to undertake broad programmes of training, including seminars, grants and exchanges of teachers, students and fellows, as well as exchanges of publications in the field of international law;

2. Requests the Secretary-General, together with the DirectorGeneral of the United Nations Educational, Scientific and Cultural Organization and in consultation with Member States, to study ways in which Members could be aided, through the United Nations system and other channels, in establishing and developing such programmes, including in this context the possibility of proclaiming a United Nations Decade of International Law dedicated to the dissemination of international law, and to report on the result of such study to the General Assembly at its eighteenth session;

3. Decides to include in the provisional agenda of its eighteenth session an item entitled "Technical assistance to promote the teaching, study, dissemination and wider appreciation of international law: report of the Secretary-General with a view to the strengthening of the practical application of international law."34

The report of the Secretary-General, referred to in paragraph 3 above, outlined an initial program of assistance and exchange in the field of international law (chapter III), with a definition of the primary role of the United Nations and UNESCO. Among the specific activities proposed were the compilation of information on training and special programs in international law; encouragement of fellowship programs and exchange of teachers, experts, students and publications; promotion of the study of legal problems of particular interest to the United Nations; and direct assistance in organizing seminars of experts on regional and world-wide bases, in instituting training and refresher courses, in financing fellowships, in furnishing advisory services of experts to member states

\footnotetext{
88 See U.N. Doc. No. A/5585, at 3-4 (1963).

sc See also U.N. Doc. No. A/5455, at 3 (1963).
} 
at their request, in granting sets of United Nations documents and publications, and in studying and standardizing methods of teaching international law. These activities were to be guided by the policy of avoiding "duplication or the taking over of programmes at present sponsored by States or other international institutions and bodies." 35

A dominant role was thus thrust upon a reluctant UNESCO, whose response was far from enthusiastic:

1. In view of the limited resources available to the Organization under its budget, UNESCO could not agree to assume all the responsibilities prescribed in chapter III of the report unless the programme of assistance and exchange in the matter of international law, which it contemplates, was entirely financed by external contributions.

2. If this were not the case, the Organization would be compelled to limit its participation in the proposed programme. Such participation could then consist only of:

(a) The inquiry and publication to which I referred in my letter of 18 July 1963 (see A/5455, Add. 1, part two);

(b) The compilation and publication of the information concerning opportunities for international studies and training;

(c) Co-operation in the administration of fellowships and scholarships offered by Governments of Member States, by the United Nations or by other international governmental or non-governmental organizations;

(d) Participation by UNESCO in the organization of two training and refresher courses .... ${ }^{36}$

At its 1281st plenary meeting held on December 16, 1963, the General Assembly requested "UNESCO to collect from member States on a periodic basis detailed information on training in international law offered by their universities and institutions of higher education and to transmit it to the Secretary-General for circulation to member States." 37 In partial compliance therewith,

${ }^{85}$ U.N. Gen. Ass. Off. Rec. 18th Sess., Annexes, Agenda Item No. 72, at 55 (1963).

so U.N. Doc. No. A/5585, at 44 (1963). (1964).

${ }^{37}$ Res. No. 1968 (XVIII), U.N. GeN. Ass. OfF. REc. 18th Sess., Plenary 1281, pt. C

This same resolution established a Special Committee on Technical Assistance to Promote the Teaching, Study, Dissemination and wider Appreciation of International Law, composed of Afghanistan, Belgium, Ecuador, Ghana, Hungary and Ireland. The Special Committee was directed to draw up a practical plan and proposals, taking into account the suggestions made in the Secretary-General's report as well as those submitted 
UNESCO has entered into a contract for a survey of the study and teaching of international law in ten or twelve countries, at an estimated cost of 4,000 dollars. The survey is to be completed in 1965. ${ }^{38}$ With this modest beginning, UNESCO has ushered in a new era. It should be noted, however, that UNESCO's Draft Programme and Budget for 1965-1966 still contains no provision relating to international law, although a comparative legal study of the newly independent countries is planned. ${ }^{39}$

It can thus be seen that the first step toward reintegrating UNESCO's activities with its original purpose might logically be to take all necessary measures to implement the General Assembly's resolutions and suggestions made by the Special Committee on Technical Assistance to Promote the Teaching, Study, Dissemination and wider Appreciation of International Law.

\section{B. Textbook on International Law for Secondary Schools}

The preparation of a textbook on international law for secondary schools, though admittedly an aspect of the teaching of international law under the preceding discussion, is nevertheless given a separate heading in order to underscore its importance. If international law is to be universally respected, it must reach as wide a segment of the world population as possible. However, in colleges and universities of the more developed nations, international law is offered, if at all, only as an optional course in political science departments or law schools. To the overwhelming majority of students, international law remains an exotic mystery, far removed

by member states, international organizations and institutions. See Res. No. 1968 (XVIII), U.N. GeN. Ass. OFF. Rec. 18th Sess., Plenary 1281, pt. A (1964).

The Special Committee met formally nine times between Nov. 25, 1964, and Jan. 29, 1965. During these meetings, it considered the preliminary draft report prepared by the Rapporteur, Mr. Erik Bal of Belgium, U.N. Doc. No. A/AC.117/L.3, and a set of suggestions made by the Chairman, Mr. E. K. Dadzie of Ghana, U.N. Doc. No. A/AC.117/L.4 and U.N. Doc. No. A/AC.117/L.5. Its conclusion called for the following: (a) steps to be taken by the U.N. and UNESCO to encourage and coordinate existing international law programs carried out by states and organizations or institutions; (b) the establishment of a U.N.-UNESCO program of direct assistance and exchange; (c) a specific plan of activities to be undertaken in 1965-1967; and (d) machinery for implementing and supervising the program. See Special Committee on Technical Assistance to Promote the Teaching, Study, Dissemination and wider Appreciation of International Law, Report, U.N. Doc. No. A/5887 (1965).

${ }^{38}$ Interview with Dr. S. Friedman, Chief of Division for International Development of Social Sciences, UNESCO, in Paris, Aug. 1964. See also Report, supra note 37.

${ }^{30}$ UNESCO, Draft Programme and Budget for 1965-1966, pt. II, ch. 3.2, II 138 (n) (1964). 
from the realities of life. For most of the people in this world, formal education does not proceed beyond the secondary school level. The percentage of people receiving higher education in the newly emergent nations is even smaller. Yet no textbook on international law has thus far existed for the use of secondary school students in any country! The reasons for this omission are twofold: the hitherto de-emphasis or even proscription, particularly in erstwhile colonies, of the study of international law; and the apprehension that international law might prove too formidable a subject for secondary school students. With the acquisition of freedom by the newly emergent nations, the first objection to the study of international law has been disposed of. With respect to the second, the argument may be made that a properly written text containing the elementary rules of international law along with the principles of the United Nations ${ }^{40}$ should be within the grasp of students in

to The teaching in schools of the purposes, principles, structure and activities of the United Nations and its related agencies has been the subject of numerous resolutions of the United Nations system. See Res. No. 1511 (XV), U.N. GEN. Ass. OFF. REc. 15th Sess., Supp. No. 16, at 22 (A/4684) (1961); Res. No. 137 (1I), U.N. GeN. Ass. OFF. REC. 2d Sess., at 45 (A/5I9) (1948); Res. No. 1012 (XXXVII), U.N. EcoSoc CounciL OFF. REc. 37th Sess., Supp. No. 1, at 29 (E/3970) (1964); Res. No. 748 (XXIX), U.N. EcoSoc Council OfF. REc. 29th Sess., Supp. No. I, at 4 (E/3373) (1960). The lastnamed resolution was sponsored by Argentina, Luxembourg and the United State8, U.N. Doc. No. E/AC.7/L.434/Rev.1 (1964), and reads:

"The Economic and Social Council,

$$
\text { .... }
$$

"1. Believes that special attention should be given in teaching about the United Nations and its related agencies to the contributions being made by them to international peace and understanding and international co-operation and particularly to their achievements in the fields of economic and social development;

"2. Expresses its appreciation for the valuable work done by non-governmental organizations in consultative status in helping to disseminate information about the United Nations and the specialized agencies, and expresses the hope that they will continue their efforts in this field;

"3. Invites the Secretary-General of the United Nations and the Director-General of the United Nations Educational, Scientific and Cultural Organization to give appropriate consideration, within existing programmes and budgets and without detriment to normal programmes, to providing study grants to textbook authors, persons responsible for educational television and radio, and persons responsible for school curriculum development, for the purpose of spending time in the Headquarters of the United Nations or of the specialized agencies to become better informed con. cerning the achievements and activities of the United Nations, as well as its structure and principles;

"4. Requests the Secretary-General, in collaboration with Director-General of the United Nations Educational, Scientific and Cultural Organization and the executive heads of other interested specialized agencies to compile a further report on teaching about the United Nations and its related agencies in schools, educational institutions and adult education programmes, on the basis of inquiries to Governments of Mem- 
the later years of secondary education. The crucial problem lies rather in the writing of an objective text. To this end, a panel of eminent jurists representing the major civilizations and legal systems of the world should be convened under the auspices of UNESCO to lay a work plan and begin a cooperative venture. Judging from the recent achievements made by the International Law Commission, where international lawyers of diverse ideologies have been able to work together to obtain consensus on some of the thorniest issues of international law, ${ }^{41}$ there is definitely ground for optimism.

\section{International Exchange Program}

Emanating from the theory that international education and cultural cooperation, by its very nature, is a type of activity which could contribute to the promotion of peaceful relations, ${ }^{42}$ UNESCO awards about 1,000 international exchange fellowships each year (as compared to 5,000 by the United Nations system as a whole and a world-wide total of 150,000$).{ }^{43}$ These fellowships vary in duration from three to nine months. The great majority of them are awarded, of course, to individuals going from less-developed countries to more-developed countries. The average recipient is about fortyfour years old and is already established in his own profession.

The selection process of the program, however, leaves much to be desired. UNESCO accepts nominations only from the govern-

ber States of the United Nations or members of the specialized agencies, for consideration by the Council in 1970;

"5. Emphasizes the importance of further efforts in the field of the production of teaching materials and audiovisual aids and assisting countries in this respect;

"6. Requests the Secretary-General and the executive heads of the specialized agencies to give a relevant importance within the existing budgets to the preparation and distribution of materials in as many different languages as possible about the structure, goals and achievements of the United Nations and its specialized agencies;

"7. Urges Governments of Member States of the United Nations or members of the specialized agencies to furnish, in response to the inquiries addressed to them, full information in their respective countries, in the public and private sectors as appropriate, particularly as regards teaching about the role of the United Nations and its related agencies in furthering social and economic development for the benefit of mankind during the United Nations Development Decade." U.N. EcoSoc CouncII OFF. Rec. 37th Sess., Supp. No. 1, at 29 (E/3970) (1964).

1 See ABA, Report of the Committee on Progressive Development of International Law and Its Codification 1963-1964 (1964); Lee, The International Law Commission Re-examined, 59 AM. J. INT'L L. 545, 547, 550 (1965).

12 UNESCO, International Cultural Co-operation 32 (IES/22/6) (1964).

$₫ 3$ Ibid. 
ment agency accredited for conducting formal relations with it, e.g., the ministry of education, the ministry of foreign affairs, or the UNESCO national commission. While there is doubtless some merit in this method, such as greater familiarity with the applicants' qualifications by a local organization, serious drawbacks also exist. In the first place, selection through nomination by government alone could easily lead to abuses. Thus, individuals have been nominated, not on their own merits, but on the basis of political reliability or patronage. This in effect defeats UNESCO's original purpose of enabling individuals unconnected with their governments to pursue their interests abroad. Furthermore, national organizations establish varying criteria, along with varying degrees of publicity or the lack of it, for their nomination processes. Sometimes the delays and bureaucratic red tape indulged in by governments are enough to dampen the ardor of even the most enthusiastic. Occasionally, there are even more fellowships available than nominees for a country which could greatly benefit from such international exchanges.

Reluctance to change the existing procedure has been based on the premise that UNESCO must not interfere with the domestic affairs of the member states. But surely some way could be found to unify and streamline the selection process without infringing upon national sovereign rights. For example, there is nothing derogatory to a nation's sovereignty in permitting all interested individuals to apply directly for fellowships to UNESCO, its regional offices, or the awarding institutions, while leaving to that nation the right of veto against a specific individual, after the fellowship has been awarded to him. This has in fact been the pattern adopted for the UNESCO travel grant program. ${ }^{44}$ The reversal of the present selection process could not fail to attract a greater number of applications from the most qualified. At the same time, it would discourage, for psychological and public opinion reasons, arbitrary actions by governments against the freest possible interchange of ideals and persons. The resulting confidence generated in such exchanges would induce even more funds from public and private sources for the expansion of the program.

\footnotetext{
4 Interview with Mr. A. Elliott, International Exchange Service, UNESCO, in Paris, Aug. 19, 1964.
} 


\section{III}

\section{ADMINISTRATION}

It is perhaps a truism to state that realization of the purpose of any organization in large measure depends upon the efficiency of its administration. This is no exception for UNESCO.

Although twenty years have elapsed since the conference in London which founded UNESCO, the latter's structure and operation are still in a state of flux. This may be attributable to both the growing pains which UNESCO has continually undergone ${ }^{45}$ and the uncertainty resulting from the controversy between peaceoriented activities and the promotion of international educational, scientiflc and cultural relations as ends in themselves. ${ }^{46}$

It may be stressed that neither of these problems has yet been resolved. UNESCO's budget and operations are still increasing by leaps and bounds, and member states are still divided over the legal-philosophical controversy. ${ }^{47}$ In such a setting inefficiency and a certain amount of demoralization among staff members are bound to occur. The problem is worse confounded by the fact that the recruitment policy is not determined solely by the merits of the individual applicants, but also by the need for equitable geographical distribution ${ }^{48}$ and political considerations. ${ }^{49}$ One result of all these factors is the time-consuming recruitment process. As of August 21, 1964, for example, 433 field posts remained vacant as against 725 already filled-a ratio of 2 to $3 ; 50$ another result is the appointment of individuals who may fit geographical and political requirements, but whose ability is unequal to the task at hand. It must be stated, however, that there is also the view that "a wide representation of the inefficient and underdeveloped peoples in the secretariat is

${ }^{45}$ From the original membership of 28 in 1946, UNESCO has grown to 115 in 1964. Its initial budget of $\$ 6,950,000$ for 1947 was increased to $\$ 9,038,199$ for 1953 , to $\$ 11,347,038$ for 1956 , to about $\$ 13,000,000$ for 1958 (in addition to $\$ 4,500,000$ from the Technical Assistance Program), to about $\$ 19,500,000$ for 1962 (in addition to $\$ 7,000,000$ from extra-budgetary sources), and to $\$ 24,500,000$ for 1965 (in addition to approximately the same amount from extra-budgetary resources).

"See discussion under section I, supra.

- UNESCO, International Cultural Co-operation, supra note 42, at 32.

$₫$ U.N. ECoSoc CoUncil Const, art. VI, \$4.

${ }^{\circ}$ See Ascher, The Development of UNESCO's Program, 4 INr'L ORGan. 12, 15 (1950).

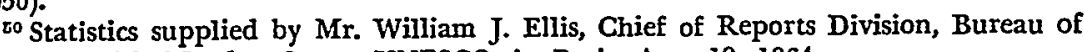
Relations with Member States, UNESCO, in Paris, Aug. 19, 1964. 
absolutely necessary to the good of the Organization."61 Mr. Luther H. Evans, the Director-General of UNESCO between 1953 and 1958, recounted the following experience:

For instance, UNESCO employed in February, 1952, an easygoing but thoughtful man from an Asian country to be a high officer of one of the program departments. He told the DirectorGeneral that he had a knowledge of French, but this turned out to be a liberal interpretation of the facts. He was slow to solve administrative problems, was not highly productive in terms of work done, and had little apparent vigor or obvious zeal. But he made a great impact on UNESCO, because he was an educated man, because he was steeped deeply in the philosophy and the culture of the East, because he was very tolerant, and because he believed ideas to be of greater importance than administrative action. As a result, he greatly increased the understanding between UNESCO and Asians. He caused the governments of Asia to become much more emotionally committed to UNESCO than they had been before. ${ }^{2}$

But, with all due respect for Mr. Evans, one may see in the above example a question of mere semantics. For, if the above Asian official increased the understanding between UNESCO and Asians and caused the Asian governments "to become much more emotionally committed to UNESCO than they had been before," he was already highly "efficient" and eminently qualified for his post! Rather, it is those who failed in their assigned tasks that are cause for concern. There is no question but that in any organization, international or otherwise, inefficiency and incompetency of those in command or in subordinate positions, if unchecked, will soon have their corrosive and corruptive influence felt throughout the organization.

Finally, there is the problem of making UNESCO an attractive prospect for one's career. Commenting on this, Dr. George $N$. Shuster, a former chairman of the United States National Commission for UNESCO and United States representative on UNESCO's executive board, said:

One cannot expect, allowance having duly been made for a few technical categories, to make a career in UNESCO. The posts are filled for periods of time, and renewal of the appointment is at

\footnotetext{
6x Evans, Some Management Problems of UNESCO, 17 INr'x ORGaN. 76, 88 (1963). 62 Ibid.
} 
the discretion of the Director-General. Retirement is mandatory at sixty, and the retirement allowances are meager. Therefore a man or woman who accepts a post must reckon with what he can come back to after a period of service the length of which cannot safely be predicted in advance. It is precisely this reckoning for which no provision has been made. A man who steps out of American academic life for a period of four or six years in order to serve UNESCO in Paris may well find it difficult to get back on campus at a rank commensurate with his abilities. As a matter of fact some have found it impossible. ${ }^{53}$

Indeed, the idea of a life-long career in UNESCO was discouraged by former Director-General Evans himself, who held out little promise for promotion opportunities:

It seems to me clear that there ought to be a good deal of rotation from nationality to nationality in most of the important positions. People should not expect to enter the secretariat as fresh college graduates and end up 25 years later as department directors or even as division chiefs.... To fill these high posts they should have had a high-level national experience. There should be some promotion, but the total range from entry into a career or [sic] retirement should not be spent in the Organization, with the exception of a number in clerical and in certain administrative positions. Generally speaking, the careerists should not be promoted to very high positions. ${ }^{54}$

Mr. Evans thought that morale would always be poor in an international organization when members of diverse nationalities

live in a foreign country very different from their own; are on temporary tenure, receive low salaries, have to send their children to local schools which do not fit their cultural pattern, and are struggling with a foreign language and foreign customs. ${ }^{55}$

All these are undoubtedly formidable problems confronting the future of UNESCO. While not in any way attempting to minimize

\footnotetext{
53 Shuster, UNESCO: Assessment ANd Promise 106 (1963).

Ed Evans, supra note 51, at 88-89.

As of Jan. 1, 1964, approximately 15\% (92 of 570) of UNESCO's total professional staff had remained in the same grade for more than ten years. Most of these were recruited before 1950 and were holding permanent contracts. The question was thus raised as to "whether a person deemed unworthy of advance for more than a decade is capable of the dynamic, imaginative service required in an agency responsible for world-wide intellectual leadership." U.N. EcoSoc CouncIL OFF. REc. 37th Sess., Annex $\mathrm{I}$, at $68 \mathrm{~m}(67 \mathrm{EX} / 25)(1964)$.

${ }^{6}$ Evans, supra note 51 , at 89.
} 
the difficulty of these problems, the following are some of the suggestions which are offered for consideration:

(1) The discouragement of a life-time career with UNESCO was natural and understandable during its formative years when there was a great deal of uncertainty as to purpose and program. A steady inflow of new blood and fresh ideas had to be maintained and, indeed, was vital to UNESCO if it were not to lapse into stagnation in the face of mounting and differing demands. With the passing of this early period in which many trials and errors were made, however, a different type of talent is now called for: the talent for consolidating, regrouping, and strengthening past gains. Maximum contribution in this regard could be rendered only by men who are long acquainted with the various facets of UNESCO's operations and who would devote their lifelong careers to international organizations. It is no accident that the United Nations General Assembly should at this particular juncture adopt Resolution 1934 (XVIIl), requesting the Secretary-General to take the necessary steps to establish a United Nations Training and Research Institute.60 The latter aims at, among other things, the strengthening of the specialized agencies through training those men who will make their careers in these bodies. ${ }^{.7}$

Career opportunities at UNESCO thus ought to be made more attractive so as to enable men with ability and conviction to remain with UNESCO for a long period of time. Although adequate financial rewards remain an important incentive for would-be careerists, this factor no longer constitutes as serious a problem today as it did in the early period of the organization. Rather, the stress today in recruiting should be more indirect: Establishment of stability and fairness of administration, consistency and purposefulness of program, and an altruistic and messianic spirit, ${ }^{68}$ will automatically alleviate recruiting problems.

\footnotetext{
${ }^{56}$ The resolution was adopted on the report of the Second Committee, Plenary 1276, U.N. Doc. No. A/5653 (1963).

${ }^{87}$ See generally Cox \& Mathiasen, United Nations Training and Research INSTTUTE (1964).

${ }^{88}$ The resemblance of UNESCO to the Church is posited in the following passage from Thomas, U.N.E.S.C.O. 186-87 (1962): “[L]Unesco n'est pas sans ressemblance avec l'Église qui, elle aussi, veille à l'éducation de la jeunesse et des adultes, ì la diffusion du savoir et de la culture, mais ne perd jamais de vue que les vrais biens qu'elle dispense ne sont pas ceux de ce monde."
} 
(2) Both the long-term and short-term recruitment processes may be improved through greater collaboration between UNESCO and member states. For example, despite the fact that the United States contributes about one-third of UNESCO's budget, it is far from having the representation in the headquarters Secretariat to which it is entitled, and its representation in the field posts is even less: As of August 19, 1964, only 31 of 725 field posts of all UNESCO's programs were occupied by United States citizens-a scant 4.28 per cent. ${ }^{69}$ The reason for this poor participation ${ }^{60}$ could not be a lack of motivation on the part of the American people; the onrush of applications for admission to the Peace Corps, which pays a much lower scale of salary, would alone refute this. Rather, a major answer lies in the inadequate publicity given to UNESCO's vacant posts throughout the United States. The International Recruitment Service of the Department of State is seriously understaffed, and the responsible official in the Education Mission Section of the Office of Education in the Department of Health, Education, and Welfare could only devote one-half of his time to UNESCO. ${ }^{61}$

Here, perhaps, the United States National Commission for UNESCO could render a valuable service. In cooperation with the Department of State and the Department of Health, Education, and Welfare, the Commission could, like the United Kingdom Department of Technical Cooperation and the Belgian Ministère de l'Education Nationale et de la Culture, publish periodic bulletins listing opportunities overseas with UNESCO for distribution to all educational institutions and interested organizations. It may be noted that UNESCO currently issues in mimeographed form a monthly list of vacancies and a quarterly status of recruitment, both of which would be useful for the above undertaking.

In addition, immediate steps should be taken toward implementing the recommendations of the State Department's Advisory

${ }^{50}$ Statistics supplied by Mr. William J. Ellis, Chief of Reports Division, Bureau of Relations with Member States, UNESCO, in Paris, Aug. 19 and 21, 1964.

${ }^{60}$ Part of the reason, according to Shuster, is that United States citizens "covet the higher, more responsible positions and do not vie for the more subordinate ones; and persons who are qualified for such positions usually have all sorts of other attractive opportunities." SHuster, op. cit. supra note 53, at 106.

${ }^{01}$ Interview with Mr. J. Howe of the Bureau of Personnel, UNESCO, in Paris, Aug. 19, 1964. 
Committee on International Organizations. ${ }^{62}$ As its Chairman, Sol

${ }^{62}$ See U.S. Dep't of State, Staffing International Organizations (1963). Members of the Advisory Committee were Messrs. Sol M. Linowitz, Harding F. Bancroft, Karney A. Brasfield, Andrew W. Cordier, Lawrence S. Finkelstein, Ernest A. Gross, Arthux Larson, Joseph Pois, Marshall D. Shulman, and Francis O. Wilcox.

In view of the importance of the report, the summary of its major recommendations, id. at 1-2, is reproduced below:

"1. The United States has an obligation under the U.N. Charter to seck to maintain, and where possible, to improve the quality of personnel and of personnel administration in the international agencies.

"2. The President should announce a positive policy of assisting international organizations to recruit competent Americans as they may be needed, utilizing to the fullest the resources of all Government departments and of appropriate private organizations.

"3. It is recommended that a position of Special Assistant to the Assistant Secretary for International Organization Affairs be set up with the function of developing and directing the execution of a single U.S. recruiting policy. The incumbent would serve as a central information and record point, would evaluate the effectiveness of U.S. recruiting efforts and would coordinate the efforts of U.S. missions. Actual recruitment would be decentralized to U.S. Government agencies which are counterparts of the U.N. agencies. Where counterpart agencies do not exist, responsibility for recruitment would rest with an International Recruiting Service in the State Department. A coordinating mechanism for international recruitment should be developed to facilitate access to the total personnel operations of the Government, and, particularly in the case of certain special abilities required in technical assistance assignments, full cooperation of business and industry should be cncouraged.

“4. To serve total U.S. purposes, arrangements should be made to facilitate the cooperative use by the Agency for International Development (AID) and the Depart. ment of State of the AID recruiting and placement mechanisms for bilateral aid and the counterpart U.S. Government mechanisms for multilateral aid. There should be a definite U.S. policy that service in either multilateral or bilatcral aid organiza. tions is a part of the career ladder for personnel of Government agencies.

"5. The United States should support a proposed U.N. study of emoluments for personnel serving in multilateral and bilateral assistance programs in order to establish comparability of information for employment purposes. In addition, the United States should support a coordinated policy for emoluments for all international agency personnel.

"6. Government agencies and private industry should be encouraged to relcase $\mathrm{cm}$ ployees for fixed term international organization service in connection with career development programs.

"7. The obtaining of adequate vacancy information should be incorporated in the reporting instructions for U.S. missions to international organizations.

"8. A current inventory of U.S. personnel serving in international organizations should be maintained by the Department of State.

"9. Attention should be paid to the recruitment of junior officers to the extent that career opportunities for them in international service are known to exist.

"10. It is recommended that an amendment to Public Law $85-795$ be sought to permit: (a) secondment of Forcign Service officers to international organizations when appropriate; and (b) the extension to 5 years of the period during which a Federal employee may serve an international organization while retaining the rights and privileges of Federal Service.

"11. The United States should adopt an appropriate program of orientation for U.S. personnel selected for service in international organizations.

"12. It is desirable and proper that U.S. missions overseas and in New York accord increased recognition to American nationals who are serving in international organization. 
M. Linowitz, stated in his letter of transmittal, dated April 22, 1963:

If the United States is fully to discharge its obligations [under the charter of the United Nations], it must play a far more effective role than it has in the past in assisting the leadership of these organizations to meet their personnel requirements.

Finally, the idea of the late Secretary-General of the United $\mathrm{Na}$ tions, Dag Hammarskjöld, that member states make their officials available for service with the United Nations Secretariat for a limited duration, could be more widely practiced at UNESCO. So far only a few East European states have engaged in such a practice on a regular basis.

(3) The organization and structure of UNESGO needs considerable improvement. Since it is obviously not the province of this paper to enter into a detailed analysis of the technical aspect of this problem, it suffices to draw attention to the Management Survey Report submitted to the Director-General of UNESCO on March 13, 1964."3 The survey team consisted of four experts selected by the Director-General pursuant to Resolution 30.2 of the General Conference adopted at its 12 th session. ${ }^{64}$ This team spent eight months, both at UNESCO's headquarters and at its overseas posts, in studying: "(i) the organization of the Departments of Education and Natural Sciences; (ii) the administrative organization, supervision and direction of UNESCO's field programme"; and (iii) "the problem of appointment of staff and related ques-

"13. There is need for all U.S. agencies concerned with the activities of international organizations to contribute to the identification of posts which as a matter of priority must be filled with persons of great professional competence.

"14. The Department of State should revise the instructions to missions to international organizations to include an assignment of responsibility in the area of staffing and personnel administration, and to provide that the responsibility be placed with a single top level officer.

"15. Appropriate efforts should be made from time to time to inform the American public of the importance the U.S. Government attaches to service in international organizations."

${ }^{8} 8$ U.N. EcoSoc Counatl OFF. REc. 37th Sess. (67EX/25) (1964).

as Members of the team were Mr. J. J. Corson (U.S.A.), director of the survey team, a director of McKinsey and Co. and Professor of Public Administration at Princeton University; Mr. A. A. Aroutunian (U.S.S.R.), official of the Ministry of Foreign Affairs, former ambassador to Canada and delgate to numerous international agencies; Mr. S. F. Hessel (France), Director of Co-operation, Ministry of National Education; and Mr. W. F. Houghton (U.K.), Education Officer to the London County Council. Id. at 2. 
tions" under (i) and (ii). ${ }^{65}$ What emerged was a seventy-nine-page document containing a detailed analysis of the existing structure, and recommendations for improvement. Seven major recommendations for prompt action by the Director-General were made:

1. Accelerate the delegation of greater authority to responsible officials throughout Unesco, a step already begun by the Director-General.

2. Revise the processes by which Unesco recruits, contracts with, promotes, and evaluates the work of its staff.

3. Clarify the responsibilities of the two major program departments-Education and Natural Sciences.

4. Redesign and stabilize the organizations of the Education and Natural Sciences Department.

5. Focus Unesco's activities in each member state and restructure the field organization. ing.

6. Streamline existing processes of programming and budget-

7. Evaluate the methods by which Unesco gets its work done.08

There is no doubt but that many of the report's recommendations, if acted upon, would greatly remedy the present defects in the UNESCO system. But their actual implementation remains a question mark, at least for the time being. The report, in its efficiency-minded forthrightness so characteristic of the American approach, has not been accorded a cordial reception by the DirectorGeneral. The latter, a Frenchman of letters steeped in the European tradition, may indeed have viewed the report's criticisms as a personal affront. The following excerpt from the report and the response it evoked from the Director-General may provide a clue to how a cultural gap-one which UNESCO was ironically intended to bridge between nations-may yet hamper an efficient overhaul of UNESCO itself:

Report:

The Director-General (and as he directs, the Deputy DirectorGeneral) must devote much of their time to contacts with the Heads of State and principal officials of the Member States. They necessarily are away from Paris on official missions for a significant portion of their time (in 1963, more than one-fourth of all working days). The large importance of the Director-General's func-

\footnotetext{
${ }^{\circ B} I d$. at 1 .

${ }^{86}$ Id. Annex I, I 2, at 6.
} 
tion demands that he give priority on many occasions to the diplomatic responsibilities of his Office. ${ }^{67}$

\section{Director-General:}

The experts calculated that, in 1963, the Director-General and the Deputy Director-General were away from Paris on official missions for more than a quarter of the year. This figure, which gives the impression of both our Offices being on a prolonged vacation is of course the total of the time spent on mission by $\mathrm{Mr}$. Adiseshiah [Deputy Director-General] and myself. In fact, these missions were seldom simultaneous and we were both absent from Paris at the same time for 14 working days only. ${ }^{68}$

It is earnestly hoped that, after a cooling-off period, the substance of the report may yet be accorded the serious attention it deserves in a constructive light.

\section{Conclusions}

As stated earlier in this paper, the preceding proposals were selective in nature and by no means intended to be exhaustive. Space now permits only a few additional remarks in summary form.

There is no doubt but that many of UNESCO's projects were conceived in direct response to the urgent needs of the times, and the end results have more than justified them. Among these, two may be singled out for mention.

The first is the East-West Major Project (Mutual Project on Mutual Appreciation of Eastern and Western Cultural Values). Adopted at the General Conference in New Delhi in $1956^{69}$ and put into action the following year, the project was designed to promote mutual cultural understanding between Asia and the West through such media as colloquies, publications, exchanges of teachers and students, art exhibits, movies, music, etc. In addition, the establishment of "associated institutions" in different regions was encouraged in order to give continuity and permanence to such programs. Although the project is due to be terminated in 1966, its excellent accomplishments and the uniformly high praises accorded

\footnotetext{
"7 Id. If 5 .

${ }^{\mathrm{a}}$ Id. Annex II, at 3 n.I.

Two other major projects were adopted at the same time: the Major Project on the Extension and Improvement of Primary Education in Latin America, which aimed at doubling the number of primary school students in Latin America within ten years, in addition to lengthening their time of study; and the Major Project on Scientific Research on Arid Lands, which sought to make arid lands more productive.
} 
to it may justify its continuation or even expansion to cover cultural exchanges involving other regions of the world.

The second is a series of international collaborative efforts in the field of natural sciences, such as the International Geophysical Year; the International Hydrological Decade; the Oceanographic Commission; and the proposed international collaboration in the study of the earth's crust and upper mantle, and especially of earthquakes, in cooperation with the International Union of Geodesy and Geophysics. These joint ventures have merits not only in the immediate goals they seek to fulfill, but also in creating the proper climate and working machinery for intergovernmental cooperation, albeit on a technical level. Such cooperation, it is hoped, will produce a chain reaction which will eventually affect the political realm as well-what Professor Frederick L. Schuman calls "peace by pieces."70

A more recent project of UNESCO related directly to peace and disarmament. Following repeated resolutions by the General Assembly calling for general and complete disarmament ${ }^{71}$ and the conclusion of the United Nations' major study on "Economic and Social Consequences of Disarmament,"72 the General Conference of UNESCO in 1962 voted a resolution which emphasized the importance of "the diversion of even a small proportion of the resources which would be released by general and complete disarmament to the long-term programmes of UNESCO for the planning and development of mass communication media."73

UNESCO has since undertaken studies on the impact which a general disarmament would have on education, science and culture. Among these are the conducting of public opinion surveys concerning disarmament in France, Norway and Poland in collaboration

${ }^{70}$ Schuman, The Commonweatth of Man 314 (1st ed. 1952).

${ }^{71}$ Res. No. 1911 (XVIII), U.N. GEN. Ass. OFF. REc. 18th Sess., Supp. No. 15 (A/5618) (1963); Res. No. 1910 (XVII), U.N. GeN. Ass. OFF. Rec. 18th Sess., Supp. No. 15 (A/5597) (1963); Res. No. 1909 (XVIII), U.N. GEN. Ass. OFF. REc. 18th Sess, Supp. No. 15 (A/5617) (1963); Res. No. 1908 (XVIII), U.N. GEN. Ass. OFF. REc. 18th Sess., Supp. No. 15 (A/5571/Add.1) (1963); Res. No. 1884 (XVIII), U.N. GeN. Ass. OFF. REc. 18th Sess., Supp. No. 15 (A/5571) (1963); Res. No. 1767 (XVI1), U.N. GEN. Ass. OfF. Rec. 17th Sess., Supp. No. 17 (A/5303) (1962); Res. No. 1722 (XVI), U.N. GEN. Ass. OfF. Rec. 16th Sess., Supp. No. 17A (A/4980/Add.2) (1961); Res. No. 1378 (XIV), U.N. GEN. Ass. OFF. REc. 14th Sess. (A/4265) (1959).

${ }^{72}$ U.N. Doc. No. E/3593/Rev.1 (U.N. Pub. Sales No. 62.IX.1) (1962). For a brief description of the background and content of this study, see 1962 YEARBOOK OF UNITED NATIONS 189-97.

${ }^{73}$ Cited in UNESCO Courier, Nov. 1964, p. 4. 
with the European Centre of Co-ordination of Research and Documentation in Vienna; the establishment of a scientific study group to consider how resources eventually released by disarmament could be used for basic research and also applied to new, creative programs of international cooperation in science and technology; and the undertaking of a study of how to increase the transfer from developed to developing nations of some of the potentially huge resources for education which would become available through disarmament.74 In view of the original purpose of UNESCO and the huge arms costs of 120 billion dollars a year world over, ${ }^{75}$ this project of preparing man's mind for disarmament could not but be an unqualified blessing to all mankind.

Since "peace" and "security" often have political overtones, it is small wonder that UNESCO has on many occasions become the arena of political and ideological battles. The yearly debate on China's representation is a case in point. ${ }^{76}$ During the Korean War, the Executive Board decided that UNESCO should give all possible aid and assistance to the United Nations action in Korea. ${ }^{77}$ At the 1964 General Conference in Paris, the United States, foreshadowing its fight in the General Assembly to strip the Soviet Union of its vote for refusing to pay its assessments for United Nations peacekeeping operations in the Congo and Cyprus, ${ }^{78}$ sought to deny

7 Id. at 21.

${ }^{75} I d$. at 5 (estimate for 1962). For 1964, total armaments expenditures were reported to have risen to between $\$ 130$ billion and $\$ 140$ billion. Ibid.

"7 By a vote of 50 to 35, the General Conference of UNESCO on Oct. 20, 1964, again defeated a Soviet-led attempt to substitute the People's Republic of China for the Republic of China. N.Y. Times, Oct. 21, 1964, p. 13, col. 1 .

${ }^{77}$ UNESCO, Report of the Director-General on the Activities of the Organization from April 1950 to March 1951, U.N. Doc. No, 6C/3 at 127-28 (1951).

${ }^{78}$ The charter of the United Nations denies a member the right to vote in the General Assembly if the amount of its arrears in the payment of its financial contributions "equals or exceeds the amount of the contributions due from it for the preceding two full years." U.N. ChARTER art. 19. Under an advisory opinion of the International Court of Justice rendered on July 20, 1962, the expenditures authorized for operations in the Congo by the General Assembly resolutions from Dec. 20, 1960, to Oct. 30, 1961, and those authorized for the operations of the U.N. Emergency Force in the Middle East from Nov. 26, 1956, to Dec. 20, 1960, constitute "Expenses of the Organization" within the meaning of art. 17, \2. Under this formula, art. 19 would become applicable if the Soviet Union and other countries refused to pay the assessments made by the General Assembly to defray the costs of these two operations. See CERTAIN EXPENSES OF THE UNITEd NAtIons (ARTICle 17, PARAgraph 2, OF THE CHARTER) 151 (I.C.J. 1962) (advisory opinion). For a penetrating analysis of this opinion, see Gross, Expenses of. the United Nations for Peace-Keeping Operations: The Advisory Opinion of the International Court of Justice, 17 INT'L ORGAN. 1 (1963).

In order to avoid a confrontation between the great powers, the 19th session of 
Bolivia, Chile and Paraguay their votes in UNESCO because of their arrears in payment. ${ }^{79}$ All three countries, however, won the right to retain their votes by invoking the escape clause, section 8 (c) of article IV, which permits a member state to vote if the General Conference "is satisfied that the failure to pay is due to conditions beyond the control of the Member Nation."

Again, membership in UNESCO of three divided States-Germany, Korea and Viet Nam-is confined to the pro-West halves. To the Eastern halves, the door is shut.

These political battles are perhaps unavoidable in any international organization. Yet, if UNESCO were to effectively fulfill its purpose, the element of politics should be removed as far as possible from its arena. In this connection, the relations of each national commission with its foreign office, delegation to UNESCO, and UNESCO itself may well be reexamined with an eye to providing for direct expression of the commission's views and policies in UNESCO with minimal delays or modification. For more than any single body in this world community, UNESCO has as its goal the consummation of the human spirits enshrined in nobility and idealism, far transcending mundane caviling and politicking. Let

the General Assembly resorted to seeking the consensus of all members, instead of voting, as a means of conducting its activities. This greatly impeded the work of the Assembly. In Feb. 1965, just before the Assembly's recess, Albania sought to force a vote by proposing that the Assembly resume its normal functioning. In the ensuing vote on recess, the United States did not challenge the Soviet right to vote, on the ground that only a procedural issue was involved. A 33 -member Special Committee on Peace-keeping Operations was subsequently appointed to undertake a comprehensive review of "the whole question of peace-keeping operations in all their aspects, in. cluding ways of overcoining the present financial difficulties of the Organization." Res. No. 2006 (XIX) (Feb. 18, 1965); see U.N. Doc. No. A/AC.121/4, at 2 (1965); U.N. Doc. No. A/5915/Add.l, Annex II, at 2 (1965).

At the I5th meeting of the Special Committec on Aug. 16, 1965, U.N. Doc. No. A/AC.121/PV.15, Ambassador Goldberg announced that, in deference to the view of the majority members, the 20th session of the General Assembly should follow normal procedure. The United States would therefore not press for the application of art. 19 to arrears arising out of the Congo and Cyprus operations. For brief comments, sce Lee, An Alternative Approach to Article 19, 59 AM. J. INT'L L. 872 (1965).

${ }^{7}$ U.N. EcoSoc Council CoNST. art IV, $\$ 8$ (b) provides: "A Member State shall have no vote in the General Conference if the total amount of contributions due from it exceeds the total amount of contributions payable by it for the current year and the immediately preceding calendar year."

${ }^{80}$ U.N. EcoSoc Council Const. art. IV, $\$ 8$ (c); see N.Y. Times, Oct. 28, 1964, p. 13, col. 1. For an explanation of the United States position in UNESCO, see letter from Francis T. P. Plimpton, the Deputy Representative of the United States to the United Nations, to the Times, Nov. 8, 1964, N.Y. Times, Nov. 10, 1964, p. 46, col. 5. 
UNESCO remain an oasis of the pure and a sanctuary for the visionary.

Even as this paper is being written, construction crews are busy hammering away in a cacophonous, rumble-jumble of noise at UNESCO's headquarters-building extra quarters for the everexpanding needs of UNESCO. In accordance with the zoning regulations of Paris, the new quarters are being built downward instead of upward. Whether this symptomizes the deepening of man's roots so that the resultant flowering will be more luxuriant, or merely reflects the absence of space in this crowded world for UNESCO, only time will tell. 